\title{
Germination and vigour in genotypes of forage sorghum at different levels of water and salt stress
}

\section{Germinação e vigor de genótipos de sorgo forrageiro em diferentes níveis de estresse hídrico e salino}

\author{
Luma Rayane de Lima Nunes ${ }^{1 *}$; Miller Clementino Cruz²; Charles Lobo Pinheiro; \\ Geocleber Gomes de Sousa ${ }^{3}$; Alek Sandro Dutra ${ }^{4}$
}

\section{Highlights:}

Germination is affected by a reduction in osmotic potential under conditions of both water and saline stress. Under water stress, the cultivars (EA 116 and BRS Ponta Negra) showed different germination behaviour. Above-ground growth in the seedlings of forage sorghum was affected by both mannitol and $\mathrm{NaCl}$.

\begin{abstract}
Salinity and water deficiency are abiotic factors which have a strong impact on agricultural activities, especially in arid and semi-arid regions. The aim of this research was to analyse the tolerance of two genotypes of forage sorghum, EA 116 and BRS Ponta Negra, to different levels of water and salt stress during germination. The conditions of water and salt stress were simulated by moistening the substrate with a solution of mannitol and of sodium chloride $(\mathrm{NaCl})$ respectively, with the water potential adjusted to 0 (distilled water), $-0.1,-0.2,-0.3,-0.4,-0.5$ and $-0.6 \mathrm{MPa}$. The variables under analysis were germination percentage, first count, germination speed index, shoot and root length, seedling dry weight, electrolyte leakage and leaf $\mathrm{Na}^{+} / \mathrm{K}^{+}$ratio. The experiment was conducted in a completely randomised design, and distributed in a 2 (genotypes) $\times 2$ (stress condition) $\times 7$ (osmotic potential) factorial scheme, with four replications. The EA 116 and BRS Ponta Negra genotypes show greater tolerance to water stress. The EA 116 cultivar maintained germination under water stress from 0 to -0.6 $\mathrm{MPa}$ and saline stress from 0 to $-0.4 \mathrm{MPa}$.
\end{abstract}

Key words: Sorghum bicolor. Homeostasis. Tolerance. Abiotic stress.

\section{Resumo}

\begin{abstract}
A salinidade e a deficiência hídrica são fatores abióticos com forte impacto sobre as atividades agrícolas, especialmente, em regiões áridas e semiáridas. Objetivou-se com a pesquisa analisar a tolerância de dois genótipos de sorgo forrageiro, EA 116 e BRS Ponta Negra, a diferentes níveis de estresse hídrico e salino durante a germinação. As condições de estresse hídrico e salino foram simuladas a partir do umedecimento do substrato com solução de manitol e Cloreto de Sódio $(\mathrm{NaCl})$, respectivamente, com potencial hídrico ajustadas em: 0 (água destilada); $-0,1 ;-0,2 ;-0,3 ;-0,4 ;-0,5$ e $-0,6 \mathrm{MPa}$. As variáveis
\end{abstract}

\footnotetext{
${ }^{1}$ Discentes do Curso de Doutorado, Programa de Pós-Graduação em Fitotecnia/Agronomia, Universidade Federal do Ceará, UFC, Fortaleza, CE, Brasil. E-mail: lumanunes20@hotmail.com; charlesclp@yahoo.com

2 Eng $^{\circ}$ Agr $^{\circ}$, Universidade da Integração Internacional da Lusofonia Afro-Brasileira, UNILAB, Redenção, CE, Brasil. E-mail: agromedicinalmuller@gmail.com

3 Prof., UNILAB, Redenção, CE, Brasil. E-mail: sousagg@unilab.edu.br

4 Prof., UFC, Fortaleza, CE, Brasil. E-mail: alekdutra@ufc.br

* Author for correspondence
} 
analisadas foram Porcentagem de germinação, primeira contagem, índice de velocidade de germinação, comprimento da parte aérea e radicular, massa seca da plântula, extravasamento de eletrólitos e a relação $\mathrm{Na}^{+} / \mathrm{K}^{+}$das folhas. Conduzido em delineamento inteiramente casualizado, distribuídos em esquema de fatorial 2 (genótipos) $\times 2$ (condição de estresse) $\times 7$ (potencial osmótico), com quatro repetições. Os genótipos EA 116 e BRS Ponta Negra apresentam maior tolerância ao estresse hídrico. A cultivar EA 116 manteve a germinação em condições de estresse hídrico de 0 a $-0,6 \mathrm{MPa}$ e salina de 0 a -0,4 MPa.

Palavras-chave: Sorghum bicolor. Homeostase. Tolerância. Estresse abiótico.

\section{Introduction}

Abiotic factors, such as salinity and water deficit, drastically affect the production of plant species of socio-economic importance, especially in arid and semi-arid regions (Oliveira \& Gomes, 2009). The effects of this stress vary over the different stages of the plant, for example, during crop establishment stress may reduce plant stand and/or negatively affect growth, with varying levels of damage, depending on the tolerance of the genotype being cultivated.

In saline soils, this restriction has been attributed to osmotic stress caused by the high concentration of salts that directly reduces the water potential, affecting the water gradient favourable to the absorption of water by the plants, and resulting in an effect similar to that of a water deficit. In addition, salinity can cause damage to the plants due to the ionic effect, which is a result of the accumulation of ions in the plant tissue (Munns \& Tester, 2008), and which affects various physiological processes of the plants. In some cases, more tolerant species develop homeostatic control mechanisms to maintain turgidity and cell growth, however, in saline environments, this concentration of ions, mainly $\mathrm{Na}^{+}$and $\mathrm{Cl}^{-}$, can accumulate in the plants at toxic levels, causing death (Souza, Machado, Silveira, \& Ribeiro, 2011).

In order to avoid or tolerate the period of stress, plants can display complex response mechanisms to water scarcity, involving detrimental and/or adaptive changes (Lisar, Motafakkerazad, Hossain, \& Rahman, 2012). Plant tolerance to water deficit is directly related to osmotic adjustment (Rhein, Santos, \& Carlin, 2011), which involves the accumulation of compatible osmoprotectants and/ or solutes inside the cell, to maintain the water gradient (Taiz, Zeiger, Moller, \& Murphy, 2017). In addition, the synthesis of these osmoprotectants also acts to reduce the harm caused by reactive oxygen species (ROS), which generally cause damage to the cell wall of plants that are in an unfavourable environment (Rhein et al., 2011).

Selecting genotypes that are more tolerant to abiotic stress is fundamental for maintaining agricultural production in regions with unfavourable climate conditions, as in these environments maintaining the supply of forage is of paramount importance, since most of the feed for animals that are exploited economically comes from pasture (sorghum, maize, Tifton grass, etc). The selection of more tolerant species and genotypes is therefore essential.

Sorghum has the potential to be grown in areas subject to problems, such as water deficit, salinity and high temperatures. In sorghum, tolerance is related to the morphological and physiological characteristics of the root system that allow an interruption in growth or a reduction in metabolic activity under water deficit, with the plants resuming growth once the stress is over (Amaral et al., 2003).

The aim of this research was to analyse the tolerance of two genotypes of forage sorghum, EA 116 and BRS Ponta Negra, to different levels of water and salt stress during germination. 


\section{Materials and Methods}

The experiment was conducted at the Seed Analysis Laboratory of the Centre for Agricultural Sciences of the Federal University of Ceará, Pici Campus, in Fortaleza, using seeds from the EA 116 and BRS Ponta Negra cultivars of forage sorghum.

The seeds were disinfected by immersing them in a 70\% alcohol solution $(\mathrm{v} / \mathrm{v})$ and agitating for 30 seconds, followed by two quick washes with distilled water. They were then immediately immersed in $2.5 \%$ sodium hypochlorite solution $(\mathrm{v} / \mathrm{v})$ for 2 minutes, washed with distilled water and then dried on paper towels. They were distributed on rolls of Germitest $^{\circledR}$ paper moistened with osmotic solution in the proportion of 2.5 times the weight of the substrate. The solutions were adjusted to concentrations of 0 (control), $-0.1-0.2,-0.3$, $-0.4,-0.5$ and $-0.6 \mathrm{MPa}$ by diluting sodium chloride or mannitol in distilled water using the formula proposed by Van't Hoff, i.e. $\Psi o s=-$ RTC, where: Yos $=$ osmotic potential $(\mathrm{atm}) ; \mathrm{R}=$ universal gas constant for perfect gases $\left(8.32 \mathrm{~J} \mathrm{~mol}^{-1} \mathrm{~K}^{-1}\right) ; \mathrm{T}=$ temperature $(\mathrm{K}) ; \mathrm{C}=$ concentration $\left(\mathrm{mol} \mathrm{L}^{-1}\right)$ and $\mathrm{T}(\mathrm{K})=273+\mathrm{T}\left({ }^{\circ} \mathrm{C}\right)$.

For each treatment, 200 seeds were used, which were distributed on paper rolls, with 50 seeds to each roll, and stored in a BOD (Biochemical Oxygen Demand) chamber at a temperature of $25 \pm 3^{\circ} \mathrm{C}$ and a photoperiod of 12 hours. The first count and the final count of the germination test were carried out on the fourth and tenth day respectively after the test was installed. The percentage of normal seedlings was determined using as classification criteria the definitions established in the Rules for Seed Analysis (Mapa, 2009). The number of normal seedlings was counted daily to calculate the germination speed index, as proposed by Maguire (1962).

Growth analysis of the shoots and roots was determined ten days after the start of the germination test, selecting ten seedlings per treatment, which were measured with a centimetre rule. The seedlings were then placed in a forced air circulation oven at a constant temperature of $65^{\circ} \mathrm{C}$ for 72 hours. They were immediately weighed on a precision balance to three decimal places to obtain the dry weight, with the results expressed in $\mathrm{mg}$ seedling ${ }^{-1}$.

Leaf membrane permeability was determined by electrolyte leakage (adapted from Tarhanen, Metsarinne, Holopainen, \& Oksanen, 1999), where $0.1 \mathrm{~g}$ of leaf discs were selected and placed in test tubes containing $10 \mathrm{~mL}$ of distilled water. These were closed and left to rest for 24 hours at an ambient temperature of $25^{\circ} \mathrm{C}$, after which, the initial conductivity (C1) was measured using a correctly calibrated bench conductivity meter. The tubes were then subjected to a temperature of $8^{\circ} \mathrm{C}$ for 60 minutes in a water bath and, after cooling, the conductivity was again checked (C2). Electrolyte leakage was calculated using the ratio $[\mathrm{C} 1 /(\mathrm{C} 1+$ C2)] x 100 (Tarhanen et al., 1999).

The extracts used to quantify the ions were prepared as per the methodology proposed by Rinner, Saurer, Streit and Siegwolf (2012). Fifty mg of dry and macerated leaves were selected and placed in test tubes containing $5 \mathrm{ml}$ of deionised water. The samples were incubated at $80^{\circ} \mathrm{C}$ for 60 min and agitated at intervals of 20 minutes. They were then centrifuged at $4,000 \mathrm{~g}$ for $15 \mathrm{~min}$ at $25^{\circ} \mathrm{C}$, and the supernatant filtered and diluted, and used to determine the $\mathrm{Na}^{+}$and $\mathrm{K}^{+}$content in a flame photometer.

The experiment was conducted in a completely randomised design, in a triple factorial scheme, 2 (cultivars) x 2 (stress conditions) x 7 (osmotic potentials), with four replications. The data were submitted to analysis of variance at $5 \%$ significance using the SISVAR ${ }^{\circledR}$ statistical software (Ferreira, 2000); for variables that showed a significant difference, the regression model with the best fit and significance was selected using the TableCurve ${ }^{\circledR}$ v5.01 software. The Sigmaplot v12.5 software was used to graph the results. 


\section{Results and Discussion}

Germination and first germination count in the forage sorghum seeds were affected by the reduction in osmotic potential, under both water and salt stress. These variables were more affected when subjected to the stress induced by $\mathrm{NaCl}$ than by mannitol (Figure 1). This can be attributed to the accumulation of $\mathrm{Na}^{+}$, changing the balance between the ions; the availability of nutrients, such as $\mathrm{K}^{+}$and $\mathrm{Ca}^{2+}$; the induction of cell damage; and a reduction in cell division and in embryo development (Dias et al., 2016). These results corroborate those obtained by Belido et al. (2016), when they state that germination in seeds of Mombasa grass was more affected in the presence of $\mathrm{NaCl}$ than in the presence of mannitol. However, Pereira, Martins, Souza, \& Martins (2012) reported that the stress simulated by PEG 6000 was more severe compared to that of $\mathrm{NaCl}$, when they saw a reduction in germination of 74 and $61 \%$ respectively in seeds of Urochloa ruziziensis submitted to an osmotic potential of -0.4 $\mathrm{MPa}$ compared to the control treatment $(0 \mathrm{MPa})$.
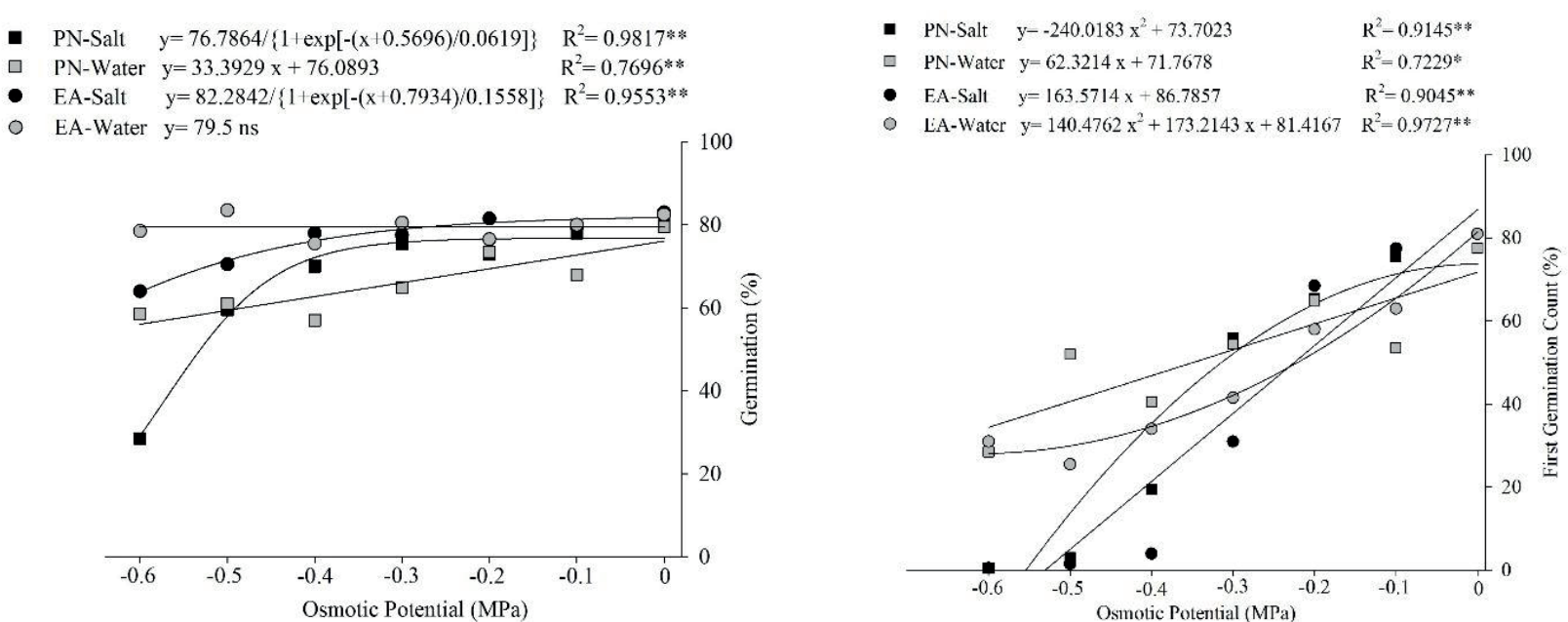

Figure 1. Germination (a) and first germination count (b) in forage sorghum cultivars under different osmotic levels induced by sodium chloride and mannitol. *significant at a level of $5 \%, * *$ significant at $1 \%$, ns - not significant.

The BRS Ponta Negra cultivar, when submitted to salt stress, maintained germination stable to a level of $-0.3 \mathrm{MPa}$. Below this potential, the germination rate gradually decreased, reaching $30 \%$ when submitted to $-0.6 \mathrm{MPa}$. Germination in the EA 116 cultivar was more tolerant to salinity, with values remaining close to $80 \%$ up to a level of $-0.4 \mathrm{MPa}$, reaching $65 \%$ for the lowest level under evaluation (Figure 1a).

These results are similar to those found by other authors. Coelho, Barros, Bezerra and Correa (2013) found that the germinative power of forage sorghum seeds was not influenced up to $10 \mathrm{dS} \mathrm{m} \mathrm{m}^{-1}(-0.25$
$\mathrm{MPa}$ ), however when exposed to a salinity of $12 \mathrm{dS}$ $\mathrm{m}^{-1}(-0.3 \mathrm{MPa})$, there was a block in all the genotypes under evaluation. Oliveira and Gomes (2009) report that germination in the species suffers a linear effect inversely proportional to the salinity. In maize, a decrease in osmotic potential significantly reduces the germination of hybrid seeds from -0.4 MPa on, due to the increase in the number of salts in the substrate (Barbieri et al., 2014).

Working with sunflower seeds, Carneiro et al. (2011) report that the induction of salt stress by $\mathrm{NaCl}$ did not affect the percentage of normal seedlings at osmotic potentials of -0.2 and $-0.4 \mathrm{MPa}$. There was a 
significant decrease at a potential of $-0.8 \mathrm{MPa}$, when only $37 \%$ of the seeds germinated, corresponding to a reduction of approximately $50 \%$ in relation to the control. Germination in maize seeds was not altered by the addition of salt, however, in less vigorous batches, there was a reduction of 3 and $4 \%$ in relation to the control (Silva, Grzybowski, \& Panobianco, 2016). Deuner, Maia, Deuner, Almeida and Meneghello (2011), working with kidney beans, found that in the absence of salt, the evaluated genotypes showed a mean germination of $93 \%$, with values remaining constant up to a concentration of $100 \mathrm{mM}$ of $\mathrm{NaCl}(-0.25 \mathrm{MPa})$. At higher concentrations, 150 and $200 \mathrm{mM}(-0.4$ and $-0.5 \mathrm{MPa}$, respectively), there was a gradual reduction in germination, falling to values of less than $10 \%$ at the highest concentration being tested.

The cultivars showed different behaviour for germination under water stress. 'EA 116' was not significantly affected, with a mean germination of $79 \%$ at the potentials under evaluation. This result agrees those of Custódio, Salomão and Machado (2009), when they found no difference in the germination of bean seeds submitted to stress simulated with mannitol. The BRS Ponta Negra cultivar showed great sensitivity to water deficit, with a linear reduction of $33.39 \%$ for each osmotic level (Figure 1a).

Several studies show that germination is also reduced in other species as the osmotic potential of the substrate decreases. Christovam et al. (2015), evaluating the seeds of Urochloa brizantha under conditions of water stress, saw a reduction in germination as the osmotic potential increased, being worse at a level of -0.9 and $-1.2 \mathrm{MPa}$. It was found that seed germination in maize, was only affected when the seeds were submitted to osmotic potentials of -0.9 and $-1.2 \mathrm{MPa}$ (Kappes, Andrade, Haga, Ferreira, \& Arf, 2010). This fall in the germination rate is due to less water being absorbed by the seeds, since the increase in osmotic concentration causes a decrease in the water gradient in the substrate, preventing the resumption of metabolic activity by the seeds (Marcos, 2015).

The cultivars showed similar behaviour for first germination count. Under water stress, 'EA 116' reached $80 \%$ germination in the control treatment ( $0 \mathrm{MPa})$, and as the osmotic potential decreased, this value was reduced by up to $28 \%$ for the lowest level tested (-0.6 MPa). A mean value of 72 and $34 \%$ respectively was seen for the BRS Ponta Negra cultivar. When submitted to salt stress, the germination rate also decreased with the reduction in osmotic potential, with germination in 'BRS Ponta Negra' falling from 74 to $14 \%$ and in 'EA 116 ' from 87 to $5 \%$ when exposed to the control and $-0.5 \mathrm{MPa}$ respectively. No germination was seen when the cultivars were submitted to -0.6 MPa. The EA 116 cultivar was more sensitive to a reduction in osmotic potential (Figure 1b).

These results are in line with those obtained by Oliveira and Gomes (2009), who found that the values for first germination count showed a linear behaviour inversely proportional to the increase in $\mathrm{NaCl}$ concentration, and who reported a difference between forage sorghum genotypes under salt stress. In the absence of a negative water potential, seeds of Urochloa ruziziensis showed a first count of $30 \%$ normal seedlings, this value decreasing to $1 \%$ when exposed to -0.4 MPa (Masetto, Ribeiro, \& Silva Rezende, 2013). In five varieties of forage sorghum, Coelho et al. (2013) found no effect from salt levels up to $10 \mathrm{dS} \mathrm{m} \mathrm{m}^{-1}(-0.25 \mathrm{MPa})$ on the germinative power of the seeds, on the fourth day after planting.

A fall in the germination speed index was seen as the osmotic potential of the substrate became more negative, with the seeds needing more time for soaking and germination. The cultivars showed a linear reduction in value for both water stress and salt stress, except 'EA 116', which, under conditions of water stress, adjusted better to the quadratic model (Figure 2). 


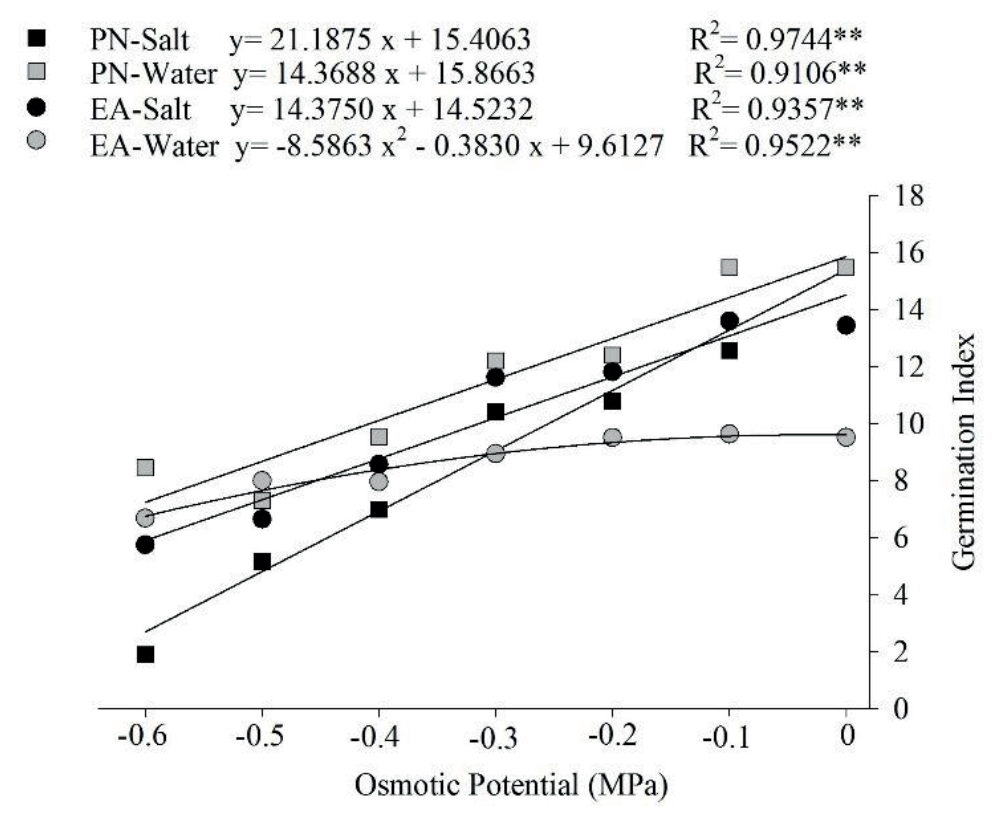

Figure 2. Germination speed index in forage sorghum cultivars under different osmotic levels induced by sodium chloride and mannitol. *significant at a level of $5 \%$, **significant at $1 \%$, ns - not significant.

When carrying out a comparison of water stress and salt stress, a reduction rate of 14.37 and $21.19 \%$ respectively was seen in the GSI for 'BRS Ponta Negra'. The EA 116 cultivar proved to be more tolerant to water stress, maintaining the same values for GSI found in the control up to an osmotic potential of $-0.3 \mathrm{MPa}$; under salt stress, there was a linear reduction of $14.37 \%$ for each reduction in osmotic potential.

For salt stress, it was found that at a potential of $-0.1 \mathrm{MPa}$ the index maintained the same value as that of the control treatment regardless of the cultivar, however, as the potential of the substrate decreased, a significant drop in value was seen, this reduction being most evident in the BRS Ponta Negra cultivar. Under water stress, the seeds showed similar behaviour to when under salt stress, with the EA 116 cultivar being most affected.
These values agree with those published by Carneiro et al. (2011), who noted that as the osmotic potential of the substrate decreases, there is a greater reduction in the physiological performance of the seedlings, and identified $\mathrm{NaCl}$ as the agent with the greatest effect on the GSI in sunflower seeds. Belido et al. (2016) state that germination speed in seeds of Panicum maximum was most affected by the water restriction.

For shoot length, the BRS Ponta Negra cultivar showed a linear reduction of 13.50 and $20.80 \%$ under water stress and salt stress respectively. In the EA 116 cultivar, the variable decreased by an average of $21.35 \%$ under salt stress, while under water stress, as the osmotic potential of the substrate decreased, the restrictions on the variable followed the quadratic model. However, at all the potentials tested, the EA 116 cultivar showed a superior shoot length to that of 'Ponta Negra' (Figure 3a). 

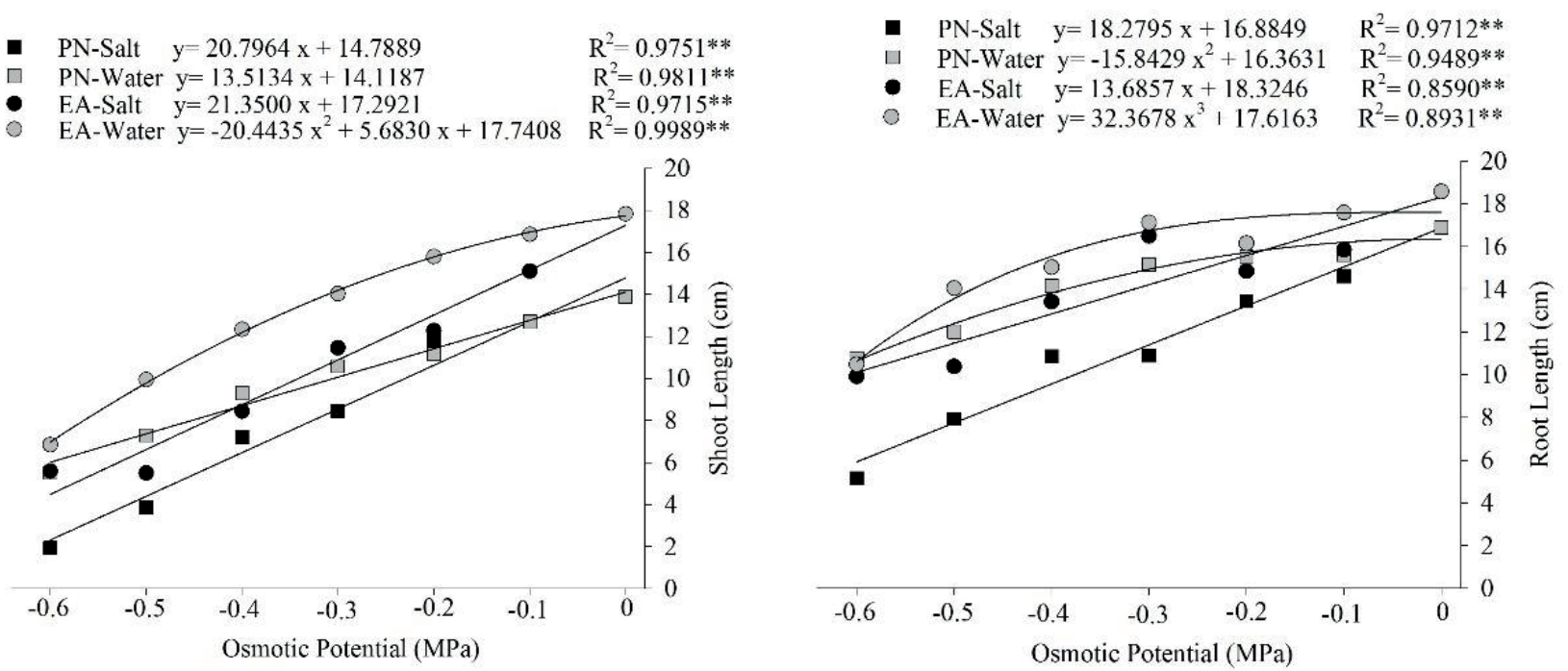

Figure 3. Shoot (a) and root (b) length in seedlings of forage sorghum cultivars under different osmotic levels induced by sodium chloride and mannitol. *significant at a level of $5 \%$, ** significant at $1 \%$, ns - not significant.

Salinity was the most limiting to growth: as the osmotic potential of the substrate became more negative, smaller seedlings were obtained, reaching 2 and $6 \mathrm{~cm}$ for 'BRS Ponta Negra' and 'EA 116' respectively at the lowest level evaluated. In such environments, the high concentration of $\mathrm{Na}^{+}$and $\mathrm{Cl}^{-}$in the cells causes protein denaturation and destabilisation of the membranes by reducing the hydration of these macromolecules (Taiz et al., 2017), impairing plant growth and development; this is particularly due to the reduction in water potential of the cell and to the toxicity of $\mathrm{Na}^{+}$and $\mathrm{Cl}^{-}$(Flowers \& Flowers, 2005).

The maximum shoot length was found in the absence of salinity, with a mean growth of 17.30 and $14.80 \mathrm{~cm}$ for 'EA 116' and 'BRS Ponta Negra'. When exposed to the lowest tested osmotic potential (-0.6 MPa), these values decreased to 4.48 and 2.31 $\mathrm{cm}$. Under water stress, the values were 17.74 and $6.96 \mathrm{~cm}$ for 'EA 116', and 14.12 and $6.00 \mathrm{~cm}$ for 'BRS Ponta Negra' respectively (Figure 3a).

When evaluating the influence of mannitol and $\mathrm{NaCl}$ on shoot development in Panicum maximum, Belido et al. (2016) reported no statistical difference between the osmotic agents; however, as the water potential of the substrate decreased, smaller seedlings were seen. Despite Barbieri et al. (2014) finding a linear reduction in maize 'BRS 3003' for a reduction in osmotic potential, in the same species, shoot length remained statistically similar up to a potential of -0.8 and $-1.2 \mathrm{MPa}$ when the germination substrate was moistened with a solution of $\mathrm{KCl}$ and $\mathrm{NaCl}$ respectively (Conus, Cardoso, Venturoso, \& Scalon, 2009). Seedlings of Urochloa ruziziensis were also negatively affected by the limited water availability of the substrate (Masetto et al., 2013).

Root growth in the seedlings showed similar behaviour to that seen in the shoots. Root length in the Ponta Negra cultivar when under water stress remained constant up to a potential of $-0.2 \mathrm{MPa}$ and, when submitted to salt stress, showed a linear decrease of $18.28 \%$. In the presence of mannitol, the roots of the EA 116 cultivar were larger compared to those of the BRS Ponta Negra cultivar at each of the potentials under analysis, proving it to be better adapted to water deficit (Figure 3b).

A reduction in root growth in other species has been reported by various authors. Kappes et al. (2010) state that, when induced to potentials of -0.3 and -0.6 MPa under water stress simulated with 
mannitol, the roots of maize hybrids did not differ from those of the control treatment. In seedlings of Panicum maximum 'Mombasa', an increase was seen up to $-0.6 \mathrm{MPa}$ (mannitol), whereas in the presence of $\mathrm{NaCl}$, root elongation was stimulated when submitted to $-0.2 \mathrm{MPa}$, followed by a gradual reduction (Belido et al., 2016). Maize hybrids showed a linear decrease as the salt concentration in the solution increased (Barbieri et al., 2014); however, Conus et al. (2009) reported an increase in the root system for a decrease in the osmotic potential of the solution, with $\mathrm{KCl}$ affording increments of $2.08 \mathrm{~cm}$ for each unit decrease (1.0 MPa). On the other hand, for $\mathrm{NaCl}$, growth is estimated to be of the order of $6.18 \mathrm{~cm}$ from $-0.41 \mathrm{MPa}$ on, reaching $8.05 \mathrm{~cm}$ at the lowest osmotic potential evaluated (-1.6 MPa).

Both the length of the shoots and of the root system were more affected by salt stress (Figure 3).

The dry matter content of the seedlings maintained the same values as found in the control treatment up to an osmotic potential of $-0.1 \mathrm{MPa}$, irrespective of the type of stress. The seedlings were lighter when submitted to salt stress, with the BRS Ponta Negra cultivar being more sensitive (Figure 4).

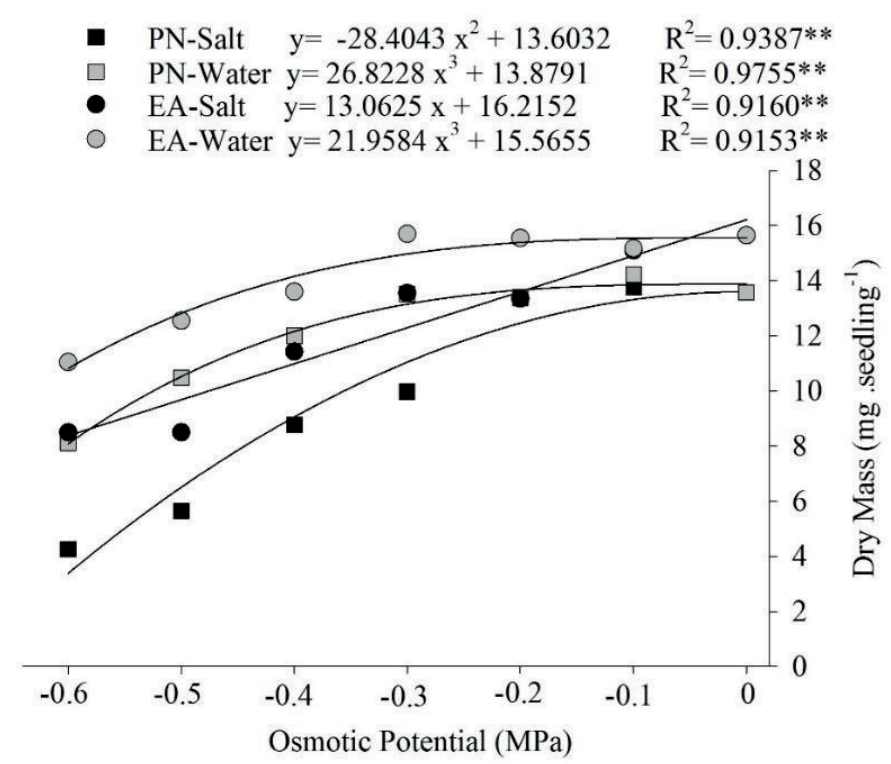

Figure 4. Dry weight in seedlings of forage sorghum cultivars under different osmotic levels induced by sodium chloride and mannitol. *significant at a level of $5 \%$, ** significant at $1 \%$, ns - not significant.

Under conditions of water stress, both cultivars showed a similar response, maintaining a certain stability in dry matter content up to a level of -0.3 $\mathrm{MPa}$, and decreasing as the osmotic potential of the substrate decreased, with the BRS Ponta Negra cultivar being more sensitive compared to 'EA 116'. In cultivars of Urochloa brizantha, Christovam et al. (2015) saw a linear reduction in dry matter content as the level of water stress increased.
For the $\mathrm{NaCl}$ concentration, the BRS Ponta Negra cultivar showed a decrease in dry matter from a potential of $-0.2 \mathrm{MPa}$, reaching values close to 3 $\mathrm{mg}$ seedling ${ }^{1}$ when submitted to $-0.6 \mathrm{MPa}$ (Figure 4). These results corroborate those found by Silva et al. (2016), who reported heavier seedlings in maize hybrids exposed to 50 and $75 \mathrm{~mol} \mathrm{~m}^{-3}(-0.13$ and $-0.19 \mathrm{MPa})$. In the same species, Barbieri et al. (2014) saw a linear reduction in dry matter as the osmotic potential of the substrate was reduced. 
Figure 5 shows the results obtained for electrolyte leakage from the shoots of both cultivars at different osmotic potentials induced by sodium chloride and mannitol. All the responses showed a linear increase in leakage as the osmotic potential decreased, irrespective of the type of stress.

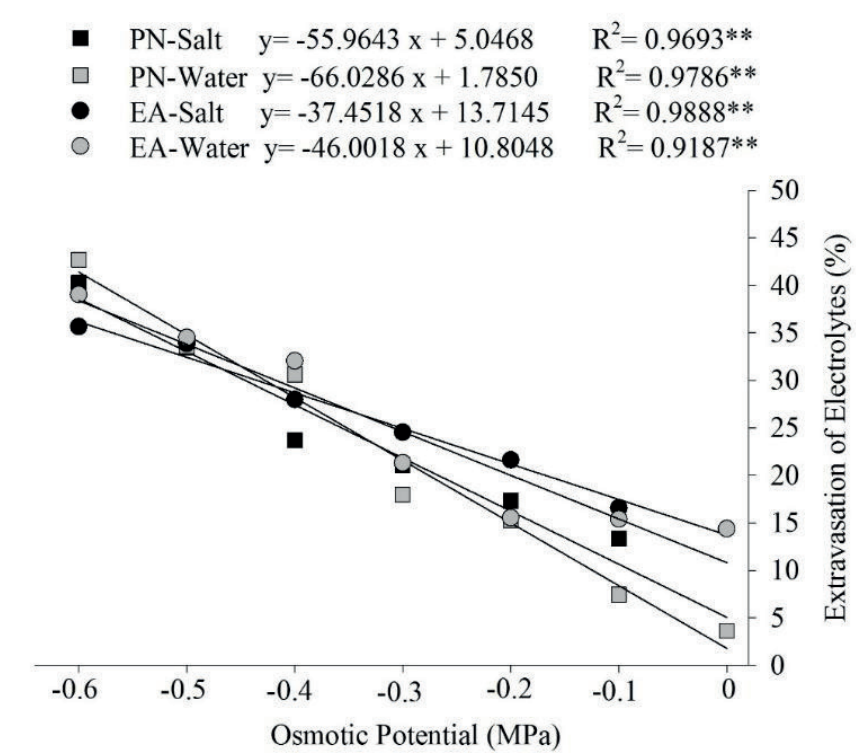

Figure 5. Electrolyte leakage in forage sorghum cultivars under different osmotic levels induced by sodium chloride and mannitol. *significant at a level of $5 \%, * *$ significant at $1 \%$, ns - not significant.

Electrolyte leakage gradually increased with the increase in $\mathrm{NaCl}$ concentration, indicating damage to the cell membranes due to lipid, protein and nucleic acid peroxidation (Pastori \& Foyer, 2002) caused by the excess of Reactive Oxygen Species (ROS) in situations of oxidative stress.

In addition to the BRS Ponta Negra cultivar behaving as sensitive to salt stress when evaluating germination and vigour, it also had the highest rates of electrolyte leakage under both types of stress. The EA 116 cultivar appeared to be more tolerant (Figure 5).

Salinity affected absorption of the $\mathrm{Na}^{+} / \mathrm{K}^{+}$ions in the forage sorghum cultivars. It can be seen that the levels of $\mathrm{Na}^{+}$in the leaves increased as the $\mathrm{NaCl}$ concentration in the substrate increased, while those of $\mathrm{K}^{+}$were reduced due to the antagonism between the ions, with the former competing for the transport sites necessary for the latter to be absorbed (Taiz et al., 2017), The selectivity of $\mathrm{K}^{+}$ ions in the roots was also reduced due to loss of membrane integrity under saline conditions (Garcia et al., 2007). (Figure 6).

The ratio between $\mathrm{Na}^{+}$and $\mathrm{K}^{+}$is closely related to the sensitivity of the plants to salinity, where the greater this ratio, the more sensitive the crop (Garcia et al., 2007). Although the two cultivars showed high values for this ratio, the EA 116 cultivar was the most affected by the increasing salt levels, reaching values of around 5.6 when exposed to -0.6 $\mathrm{MPa}$, whereas, at the same potential, the BRS Ponta Negra cultivar reached a value of 2.75 . 


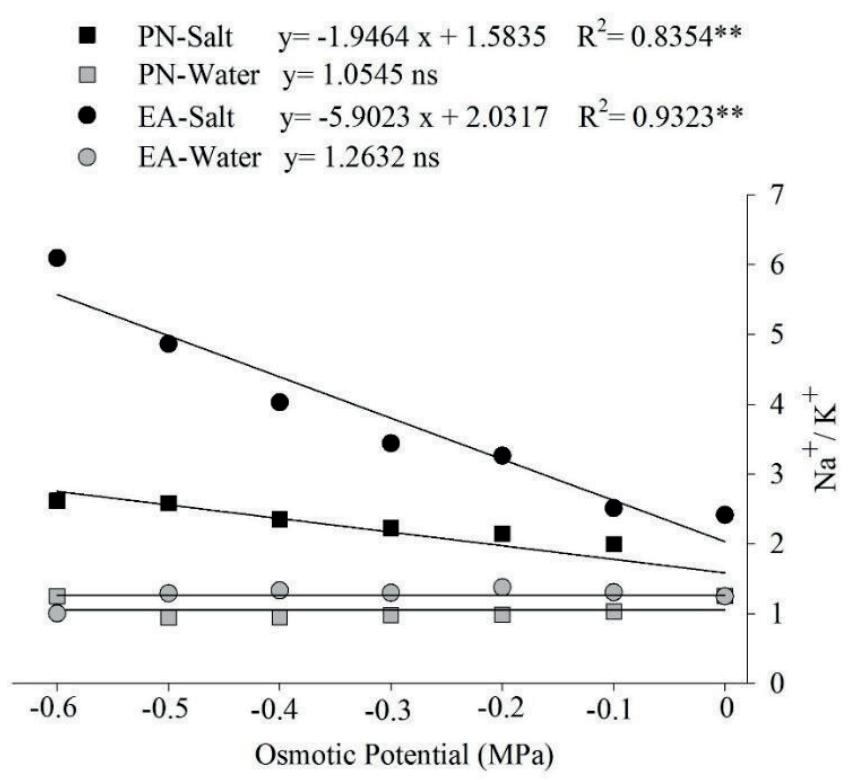

Figure 6. $\mathrm{Na}^{+} / \mathrm{K}^{+}$ratio in leaves of forage sorghum cultivars under different osmotic levels induced by sodium chloride and mannitol. *significant at a level of 5\%, **significant at $1 \%$, ns - not significant.

\section{Conclusions}

The EA 116 cultivar showed greater tolerance to water stress, maintaining germination from 0 to $-0.6 \mathrm{MPa}$. In the vigour tests, even at the lowest potential, observed values were higher than those obtained by the BRS Ponta Negra cultivar.

Despite the EA 116 cultivar continuing to germinate up to a potential of $-0.4 \mathrm{MPa}$, when analysing the $\mathrm{Na}^{+} / \mathrm{K}^{+}$ratio, it was found that this cultivar had higher values compared to 'BRS Ponta Negra', showing it to be more sensitive to salinity.

\section{References}

Amaral, S. R., Lira, M. A., Tabosa, J. N., Santos, M. V. F. S., Mello, A. C. L., \& Santos, V. F. (2003). Comportamento de linhagens de sorgo forrageiro submetidos a déficit hídrico sob condição controlada. Pesquisa Agropecuária Brasileira, 38(8), 973-979. doi: 10.1590/S0100-204X2003000800010

Barbieri, A. P. P., Huth, C., Zen, H. D., Beche, M., Henning, L. M. M., \& Lopes, S. J. (2014). Tratamento de sementes de milho sobre o desempenho de plântulas em condições de estresse salino. Revista de Ciências Agrárias, 57(3), 305-311. doi: 10.4322/rca. ao1381

Belido, I. A., Yamashita, O. M., Ferreira, A. C. T., Felito, R. A., Rocha, A. M., \& Carvalho, M. A. C. (2016). Estresse hídrico na germinação de sementes e desenvolvimento inicial de plântulas de Panicum maximum cv. Mombaça. Revista Ciências Agroambientais, 14(2), 38-46. Recuperado de https:// periodicos.unemat.br/index.php/rcaa/article/ view/1258/1525

Carneiro, M. M. L. C., Deuner, S., Oliveira, P. V., Teixeira, S. B., Sousa, C. P., Bacarin, M. A., \& Moraes, D. M. (2011). Atividade antioxidante e viabilidade de sementes de girassol após estresse hídrico e salino. Revista Brasileira de Sementes, 33(4), 752-761. doi: 10.1590/S0101-31222011000400017. Recuperado de https://submission3.scielo. br/index.php/jss/ article/view/42891

Christovam, M. C., Silva, T. L., Yamamoto, C. J. T., Moreira, A. L. L., Custódio, C. C., Pacheco, A. C., \& Abrantes, F. L. (2015). Germinação e desenvolvimento inicial de plântulas de cultivares de Urochloa brizantha em condições de estresse hídrico. Informativo Abrates, 25(3), 43-50. Recuperado de https://www.researchgate.net/ publication/299506741 
Coelho, J. B. M., Barros, M. F. C., Bezerra, E., Neto, \& Correa, M. M. (2013). Comportamento hídrico e crescimento do feijão vigna cultivado em solos salinizados. Revista Brasileira de Engenharia Agrícola e Ambiental, 17(4), 379-385. doi: 10.1590/ S1415-43662013000400004. Recuperado de http:// www. scielo.br/pdf/rbeaa/v17n4/a04v17n4.pdf

Conus, L. A., Cardoso, P. C., Venturoso, L. R., \& Scalon, S. P. Q. (2009). Germinação de Sementes e vigor de plântulas de milho submetidas ao estresse salino induzido por diferentes sais. Revista Brasileira de Sementes, 31(4), 67-74. doi: 10.1590/S010131222009000400008

Custódio, C. C., Salomão, G. R., \& Machado, N. B., Neto. (2009). Estresse hídrico na germinação e vigor de sementes de feijão submetidas à diferentes soluções osmóticas. Revista Ciência Agronômica, 40(4), 617-623. Recuperado de http:/ccarevista.ufc. br/seer/index.php/ccarevista/article/view/491/390

Deuner, C., Maia, M. S., Deuner, S., Almeida, A. S., \& Meneghello, G. E. (2011). Viabilidade e atividade antioxidante de sementes de genótipos de feijãomiúdo submetidos ao estresse salino. Revista Brasileira de Sementes, 33(4), 711-720. doi: 10.1590/S0101-31222011000400013: Recuperado de http://www. scielo.br/pdf/rbs/v33n4/13.pdf

Dias, N. S., Blanco, F. F., Souza, E. R., Ferreira, J. F. S., Sousa, O. N., Neto, \& Queiroz, I. S. R. (2016). Efeitos dos sais na planta e tolerância das culturas à salinidade. In H. R. Gheyi, N. S. Dias, C. F. Lacerda, \& E. Gomes, $\mathrm{F}^{\mathrm{o}}$. (Eds.), Manejo da salinidade na agricultura: estudos básicos e aplicados (pp. 151161). Fortaleza, NCTSal.

Ferreira, D. F. (2000). Análises estatísticas por meio do Sisvar para Windows versão 4.0. In Reunião Anual da Região Brasileira da Sociedade Internacional de Biometria. (pp. 255-258). São Carlos, SP: SIB.

Flowers, T. J., \& Flowers, S. A. (2005). Why does salinity pose such a difficult problem for plant breeders? Agricultural Water Management, 78(2), 15-24. doi: 10.1016/j.agwat.2005.04.015

Garcia, G. O., Ferreira, P. A., Miranda, G. V., Neves, J. C. L., Moraes, W. B., \& Santos, D. B. (2007). Teores foliares dos macronutrientes catiônicos e suas relações com o sódio em plantas de milho sob estresse salino. Idesia, 25(3), 93-106. doi: 10.4067/ S0718-34292007000300010

Kappes, C., Andrade, J. A. C., Haga, K. I., Ferreira, J. P., \& Arf, M. V. (2010). Germinação, vigor de sementes e crescimento de plântulas de milho sob condições de déficit hídrico. Scientia agraria, 11(2), 125-134. doi: 10.5380/rsa.v11i2.16464. Recuperado de https://revistas.ufpr.br/agraria/article/viewFile/ $16464 / 11479$

Lisar, S. Y. S., Motafakkerazad, R., Hossain, M. M., \& Rahman, I. M. M. (2012). Water stress in plants: causes, effects and responses. In M. D.. Ismail, M. Rahman, \& H. Hasegawa (Eds.), Water stress (pp. 1-14). Rijeka: Intech.

Maguire, J. D. (1962). Speed of germination-aid in selection and evaluation for seedling emergence and vigor. Crop Science, 2(1), 176-177. dói: 10.2135/cr opsci1962.0011183X000200020033x. Recuperado de https://acsess.onlinelibrary.wiley.com/doi/abs/ 10.2135/cropsci1962.0011183X000200020033x.

Mapa (2009). Regras para análise de sementes. Ministério da Agricultura, Pecuária e Abastecimento, Brasília: MAPA/ACS.

Marcos, J., Fº (2015). Fisiologia de sementes de plantas cultivadas ( $2 \mathrm{a}$ ed.). Londrina: ABRATES.

Masetto, T. E., Ribeiro, D. M., \& Silva Rezende, R. K. (2013). Germinação de sementes de Urochloa ruziziensis em função da disponibilidade hídrica do substrato e teor de água das sementes. Pesquisa Agropecuária Tropical, 43(4), 385-391. doi: 10.1590/ S1983-40632013000400010. Recuperado de https:// www.revistas.ufg.br/pat/article/ view/22634/15520

Munns, R., \& Tester, M. (2008). Mechanisms of salinity tolerance. Annual Review of Plant Biology, 59(1), 651-681. doi: 10.1146/annurev. arplant.59.032607.092911

Oliveira, A. B., \& Gomes, E., Fo., (2009). Germinação e vigor de sementes de sorgo forrageiro sob estresse hídrico e salino. Revista Brasileira de Sementes, 31(3), 48-56. doi: 10.1590/S010131222009000300005

Pastori, G. M., \& Foyer, C. H. (2002). Common components, networks, and pathways of crosstolerance to stress. The central role of 'redox' and abscisic acid-mediated controls. Plant Physiology, 129(2), 7460-7468. doi: 10.1104/pp.011021

Pereira, M. R. R., Martins, C. C., Souza, G. S. F., \& Martins, D. (2012). Influência do estresse hídrico e salino na germinação de Urochloa decumbens e Urochloa ruziziensis. Bioscience Journal, 28(4), 537545. Recuperado de http://www.seer.ufu.br/index. php/biosciencejournal/article/view/13447/9743 
Rhein, A. F. L., Santos, D. M. M., \& Carlin, S. D. (2011). Atividade da enzima redutase do nitrato e teores de prolina livre em raízes de cana-de-açúcar sob estresse hídrico e ácido no solo. Semina: Ciências Agrárias, 32(4), 1345-1360. doi: 10.5433/1679-0359.2011v32 n4p 1345

Rinner, K. T., Saurer, M., Streit, K., \& Siegwolf, R. T. W. (2012). Evaluation of a liquid chromatography method for compoundspecific $\delta 13 \mathrm{C}$ analysis of plant carbohydrates in alkaline media. Rapid Commum Mass Spectrom, 26(18), 2173-2185. doi: 10.1002/ rcm.6334

Silva, R. C., Grzybowski, C. R. S., \& Panobianco, M. (2016). Vigor de sementes de milho: influência no desenvolvimento de plântulas em condições de estresse salino. Revista Ciência Agronômica, 47(3), 491-499. doi: 10.5935/1806-6690.20160059
Souza, R. P., Machado, E. C., Silveira, J. A. G., \& Ribeiro, R. V. (2011). Fotossíntese e acúmulo de solutos em feijoeiro-caupi submetido à salinidade. Pesquisa Agropecuária Brasileira, 46(6), 586592. doi: 10.1590/S0100-204X2011000600003. Recuperado de http://www.scielo.br/pdf/pab/v46n6/ a03v46n6. pdf

Taiz, L., Zeiger, E., Moller, I. M., \& Murphy, A. (2017). Fisiologia e desenvolvimento vegetal (6a ed.). Porto Alegre: Artmed.

Tarhanen, S., Metsarinne, S., Holopainen, T., \& Oksanen, J. (1999). Membrane permeability response of lichen Bryoria fuscescens to wet deposited heavy metals and acid rain. Environmental Pollution, 104(1), 121129. doi: 10.1016/S0269-7491(98)00157-2 